\section{Flumazenil reduces the duration of thiopentone but not of propofol anaesthesia in humans}

Argyro Fassoulaki MD PhD DEAA, Constantine Sarantopoulos MD, Konstantine Papilas MD
The effect of flumazenil $(F)$ on the duration of anaesthesia produced by a single dose of thiopentone $(T)$ and propofol $(P)$ was investigated in a placebo-controlled double-blind trial. Eighty-four patients anaesthetized with $\mathrm{N}_{2} \mathrm{O}$ in $\mathrm{O}_{2}$ and either thiopentone $7 \mathrm{mg} \cdot \mathrm{kg}^{-1}$ or propofol $3 \mathrm{mg} \cdot \mathrm{kg}^{-1}$ for minor $\mathrm{gy}$ naecological procedures were studied. Patients were randomly allocated to pretreatment with either $0.5 \mathrm{mg}$ of flumazenil $(F)$ or $5 \mathrm{ml}$ of normal saline (NS) in one of the following groups: $T / N S, T / F, P / N S$, or $P / F$. Anaesthetic requirements were assessed by recording the time between the injection of anaesthetic and the first movement observed during the procedure. The time elapsed from the administration of thiopentone to the first movement was $6.5 \pm 1.6 \mathrm{~min}$ for the $T / N S$ group and 5.3 \pm 2.4 min for the $T / F$ group ( $P<0.05$ ). The first movement after propofol administration was observed at $7.0 \pm 2.2 \mathrm{~min}$ in the P/NS group and at $7.1 \pm 4.5 \mathrm{~min}$ in the $P / F$ group (NS). These data suggest that pretreatment with $0.5 \mathrm{mg}$ of $\mathrm{fu}$ mazenil iv reduces the duration of thiopentone but not of propofol anaesthesia.

Au cours d'une étude à double insu avec placebo, les effets du flumazénil $(F)$ sur la durée de l'anesthésie produite par une dose unique de thiopentone $(T)$ et de propofol $(P)$ sont évalués. La population étudiée comprend quatre vingt-quatre patientes anesthésiées au protoxyde-oxygène associé d̀ du thiopentone $7 \mathrm{mg} \cdot \mathrm{kg}^{-1}$ ou du propofol $3 \mathrm{mg} \cdot \mathrm{kg}^{-1}$ pour des opérations gynécologiques mineures. Les patientes reçoivent aléatoirement un pré-traitement au flumazénil (F) ou au soluté physiologique (NS) et sont repartis dans les groupes suivants: $T / N S, T / F$, P/NS ou P/F. Les besoins anesthésiques sont évalués par la

\section{Key words}

ANAESTHETICS INTRAVENOUS: propofol, thiopentone; ANTAGONISTS: benzodiazepines, flumazenil; POTENCY: anaesthetic.

From the Department of Anaesthesia, St Savas Hospital, 171 Alexandras Ave. Athens 11522, Greece.

Address correspondence to: Dr. A Fassoulaki, 57-59

Raftopoulo St., Athens 11744, Greece.

Accepted for publication 28th August, 1992. mesure de l'intervalle entre linjection de l'anesthésique et l'observation d'un premier mouvement pendant lintervention. Le temps écoulé à partir de l'administration de thiopentone et l'observation d'un premier mouvement est de $6,5 \pm 1,6 \mathrm{~min}$ pour le groupe $T / N S$ et 5,3 $\pm 2,4$ pour le groupe $T F(P<0,05)$. Le premier mouvement noté après l'administration de propofol est observé à 7,0 $\pm 2,2 \mathrm{~min}$ dans le groupe $P / N S$ et à 7,1 $\pm 4,5$ min dans le groupe $P / F(N . S$.$) . Ces données suggèrent$ que l'administration préalable de Flumazénil $0,5 \mathrm{mg}$ iv diminue la durée d'action du thiopentone mais non du propofol.

Flumazenil has been shown to antagonize the central effects of benzodiazepines by competitive displacement from the benzodiazepine receptor. ${ }^{1-3}$ However, the possibility that flumazenil antagonizes the anaesthetic effects of the intravenous anaesthetics thiopentone and propofol has not been examined before. This placebo-controlled double blind study investigated whether pretreatment with flumazenil altered the anaesthetic requirements of thiopentone and/or propofol, when these drugs were administered to produce general anaesthesia for minor gynaecological procedures.

\section{Methods}

After approval of the Hospital Ethical Committee, 84 patients ASA I-II, scheduled for elective dilation and curretage (D \& C) of the uterus under general anaesthesia were informed of the aim of the study in the preoperative visit and informed consent was obtained. Smokers or those receiving drugs were excluded and premedication was omitted. Patients were assigned randomly to one of four groups: thiopentone/normal saline, thiopentone/flumazenil, propofol/normal saline, and propofol/flumazenil.

After three minutes inhalation of $70 \% \mathrm{~N}_{2} \mathrm{O}$ in $\mathrm{O}_{2}$ via a Mapleson A anaesthetic system patients received randomly either flumazenil $0.5 \mathrm{mg}$ or normal saline $5 \mathrm{mg}$ $i v$. Two minutes later anaesthesia was induced with either thiopentone $7 \mathrm{mg} \cdot \mathrm{kg}^{-1}$ or propofol $3 \mathrm{mg} \cdot \mathrm{kg}^{-1} i \mathrm{v}$. The patient was placed in the lithotomy position, an oral airway was inserted, and anaesthesia was maintained with 
TABLE I Age (yr) and body weight $(\mathrm{kg})$ in each group of patients. Mean \pm sd.

\begin{tabular}{lllll}
\hline & $\begin{array}{l}\text { Thio/NS } \\
n=18\end{array}$ & $\begin{array}{l}\text { Thio/Flum } \\
n=24\end{array}$ & $\begin{array}{l}\text { Prop/NS } \\
n=21\end{array}$ & $\begin{array}{l}\text { Prop/Flum } \\
n=21\end{array}$ \\
\hline Age (yr) & $50.7 \pm 9.9$ & $45.2 \pm 9.6$ & $50.4 \pm 10.6$ & $50.9 \pm 8.5$ \\
Weight (kg) & $68.9 \pm 9.7$ & $65.4 \pm 7.6$ & $66.9 \pm 8.8$ & $67.6 \pm 10.5$ \\
\hline
\end{tabular}

Thio - thiopentone, NS - saline, Flum - flumazenil.

TABLE II Time ( $\mathrm{min}$ ) between anaesthetic administration and (a) first movement and (b) cervical dilatation in each group. Mean \pm SD.

\begin{tabular}{lllll}
\hline Time & Thio/NS & Thio/Flum & Prop/NS & Prop/Flum \\
(minutes) & $n=18$ & $n=24$ & $n=21$ & $n=21$ \\
\hline
\end{tabular}

To first movement $6.5 \pm 1.6^{*} 5.3 \pm 2.4^{*} \quad 7.0 \pm 2.2 \quad 7.1 \pm 4.5$

To cervical

dilatation $\quad 4.4 \pm 1.2 \quad 4.3 \pm 1.7 \quad 4.8 \pm 1.5 \quad 4.2 \pm 1.0$

$* P<0.05$

$\mathrm{N}_{2} \mathrm{O}$ in $\mathrm{O}_{2}$ via a face mask. Heart rate, ECG, and $\mathrm{SaO}_{2}$ were monitored continuously and blood pressure was recorded automatically every five minutes (Cardiocap, Datex).

The time that elapsed between the iv administration of the anaesthetic and (a) cervical dilation and (b) the patient's first movement, including attempts to reject the airway, were recorded. When movement occurred and the D \& $\mathrm{C}$ had not been completed anaesthesia was supplemented either with isoflurane $1 \%$ or with an opioid (fentanyl $50 \mu \mathrm{g}$ ), or both. Observations and recordings were made by an anaesthetist who was unaware of the pretreatment given and of the study design.

The age and body weight among the groups were analyzed using ANOVA. The times to first movement of the patient were analysed using the Mann-Whitney test. $P<0.05$ was considered statistically significant.

\section{Results}

The four groups of patients did not differ with regard to age or body weight (Table I).

The time from administration of thiopentone to first movement was decreased by $18.5 \%$ in the thiopentone/ flumazenil group compared with the thiopentone/normal saline group $(P<0.05)$ but there was no difference between the propofol/normal saline and propofol/flumazenil groups (Table II).

Supplemental anaesthesia-analgesia was given to six patients in the thiopentone/normal saline group, to ten patients in the thiopentone/flumazenil group, to six patients in the propofol/saline group, and to four patients in the propofol/flumazenil group.

\section{Discussion}

Flumazenil in a dose of $0.5 \mathrm{mg}$ reduced the duration of thiopentone anaesthesia but had no effect on the duration of propofol anaesthesia.

Flumazenil specifically antagonizes the effects of benzodiazepines which act on specific receptors in the brain, the GABA-and benzodiazepine receptor-chloride channel complex..$^{1-3}$ Alon et al. found a reduction in sedation and improvement in orientation and comprehension in women that received the specific antagonist after midazolam anaesthesia. ${ }^{4}$ Similar results have been reported by other investigators. Nilsson et al. reported that flumazenil administration improved performance after general anaesthesia induced with midazolam and alfentanyl but resedation occurred. ${ }^{2}$ With regard to the analgesic requirements when the antagonist is administered postoperatively to reverse benzodiazepine effects, studies are controversial; either an increase ${ }^{5}$ or no change ${ }^{2}$ have been reported. The efficacy of flumazenil to antagonize sedation, disorientation, and lack of cooperation produced by midazolam administered to patients undergoing spinal anaesthesia has been compared with that of aminophylline. Aminophylline only partially reversed the effects of midazolam, while antagonism produced by flumazenil was rapid and complete. ${ }^{6}$

Flumazenil has not been shown to reverse reliably the effects of chloralhydrate ${ }^{7}$ and the action of ethanol. ${ }^{8,9}$ The drug failed to enhance or antagonize the anaesthetic effects of halothane in rats ${ }^{10}$ and of isoflurane, enflurane, or enflurane-fentanyl anaesthesia in dogs. " These results are in contrast with those of Schwartz et al. who reported a decrease in the MAC of isoflurane by flumazenil in dogs. ${ }^{12}$

An antagonizing effect of flumazenil on the action of intravenous anaesthetics may exist, since the GABAreceptor/chloride channel stimulation has been proposed as a possible molecular mechanism of general anaesthesia produced by intravenous anaesthetics. ${ }^{13}$ However, the GABA receptor is a part of a multimolecular membrane complex, which also contains the benzodiazepine receptor, the chloride ionophore, and possibly other molecular entities. ${ }^{14}$

It has been suggested that barbiturates increase the average open life time of chloride channel and the benzodiazepines increase the frequency of chloride channel opening. ${ }^{15}$ Despite the different mechanisms potentiating the GABA response, our results suggest some interaction between thiopentone and flumazenil. On the other hand the cellular actions of propofol are not well known. Propofol potentiates the surface depolarizations evoked by GABA, muscinol and 3-aminopropanesulphonic acid in the rat olfactory cortex slices. ${ }^{16}$

The large predetermined fixed doses of both thio- 
pentone and propofol were chosen to obtain a satisfactory depth of anaesthesia in all patients. An argument may be that during $\mathrm{D}$ and $\mathrm{C}$ stimulation varies, with movement most likely to occur during cervical dilatation. Nonetheless, as the time from administration of the anaesthetic to cervical dilatation does not differ between the groups (thiopentone/normal saline vs thiopentone/ flumazenil and propofol/normal saline vs propofol/flumazenil), the timing of this powerful stimulus is unlikely to override any effect due to flumazenil.

Nitrous oxide was given prior to the $i v$ anaesthetics, so that the desired $\mathrm{N}_{2} \mathrm{O}$ alveolar concentration was obtained before respiratory depression occurred due to the iv anaesthetic. The administration of $\mathrm{N}_{2} \mathrm{O}$ in all groups might be a limitation regarding the flumazenil-iv anaesthetic interaction. Nonetheless, we did not omit analgesia produced by $\mathrm{N}_{2} \mathrm{O}$, even in such a short procedure for ethical reasons.

Another limitation of the study may be the lack of a dose response relationship. Higgit et al. showed that $100 \mathrm{mg}$ po of flumazenil in healthy subjects produced benzodiazepine-like effects, while $30 \mathrm{mg}$ po produced effects opposite to those of benzodiazepines. ${ }^{17}$ However, in our study the ampoules of flumazenil $(0.5 \mathrm{mg}$ in 5 $\mathrm{ml}$ volume, Anexate ${ }^{\circledR}$, Roche) were appropriately covered by the Hospital Pharmacy in an identical manner with the $5 \mathrm{ml}$ ampoules containing $\mathrm{NaCl}$, so that the trial was conducted double-blind. This was the reason for not obtaining a dose response curve.

In conclusion, these results suggest that flumazenil may antagonize, to some degree, the anaesthetic effects of thiopentone but not of propofol. This antagonistic effect is far less pronounced than in the reversal of benzodiazepine sedation. Whether these findings are clinically important for thiopentone anaesthesia remains to be determined.

\section{References}

1 Amrein $R$, Leishman B, Bentzinger $C$, Rocari $G$. Flumazenil in benzodiazepine antagonism. Actions and clinical use in intoxications and anaesthesiology. Medical Toxicology 1987; 2: 411-29.

2 Nilsson A, Persson MP, Hartvig P. Effects of the benzodiazepine antagonist flumazenil on postoperative performance following total intravenous anaesthesia with midazolam and alfentanil. Acta Anaesthesiol Scand 1988; 32: 441-6.

3 Tefakis Karavokiros KA, Tsipis GB. Flumazenil: a benzodiazepine antagonist. Annals of Pharmacotherapy 1990; 24: 976-81.

4 Alon E, Baitella $L$, Hossli $G$. Double-blind study of the reversal of midazolam-supplemented general anaesthesia with Ro 15-1788. Br J Anaesth 1987; 59: 455-8.
5 Jensen S, Kirkegaard L, Anderson BN. Randomized clinical investigation of Ro 15-1788, a benzodiazepine antagonist in reversing the central effects of flunitrazepam. Europ J Anaesthesiol 1987; 4: 113-8.

6 Sibai $A N$, Sibai $A M$, Baraka A. Comparison of flumazenil with aminophylline to antagonize midazolam in elderly patients. Br J Anaesth 1991; 66: 591-5.

7 Donovan KL, Fisher DJ. Reversal of chloral hydrate overdose with flumazenil. BMJ 1989; 298: 1253.

8 Scollo-Livizzari G, Matthis $H$. Benzodiazepine antagonist (Ro 15-1788) in ethanol intoxication: a pilot study. Eur Neurol 1985; 24: 352-4.

9 Klotz $U$, Ziegler G, Rosenkranz B, Mikus G. Does the benzodiazepine antagonist Ro 15-1788 antagonize the action of ethanol? Br J Clin Pharmacol 1986; 22: 513-20.

10 Greiner $A S$, Larach $D R$. The effect of benzodiazepine receptor antagonism by flumazenil on the MAC of halothane in the rat. Anesthesiology 1989; 70: 644-8.

11 Schwieger IM, Szlam F, Hug CC. Absence of agonistic or antagonistic effect of flumazenil (Ro 15-1788) in dogs anaesthetized with enflurane, isoflurane, or fentanyl-enflurane. Anesthesiology 1989; 70: 477-80.

12 Schwartz AE, Maneksha FR, Kanchuger MS, Sidhu US, Poppers PJ. Flumazenil decreases the minimum alveolar concentration of isoflurane in dogs. Anesthesiology 1989; 70: 764-6.

13 Keane PE, Biziere $K$. The effects of general anaesthetics on gabaergic synaptic transmission. Life Sciences 1987; 41: 1437-48.

14 Sigel E, Barnard EA. A gamma-aminobutyric acid benzodiazepine receptor complex from bovine cerebral cortex. Improved purification with preservation of regulatory sites and their interactions. J Biol Chem 1984; 259: 7219-23.

15 Study RE, Barker JL. Diazepam and (-)-pentobarbital: Fluctuation analysis reveals different mechanisms for potentiation of gamma-aminobutyric acid responses in cultured central neurons. Proc Natl Acad Sci USA 1981; 78 : $7180-4$.

16 Collins GGS. Effects of the anaesthetic 2,6-diisopropylphenol on synaptic transmission in the rat olfactory cortex slice. Br J Pharmacol 1988; 95: 939-49.

17 Higgitt A, Lader M, Fonagy P. The effects of the benzodiazepine antagonist Ro 15-1788 on psychophysiological performance and subjective measures in normal subjects. Psychopharmacology 1986; 89: 395-403. 